\title{
The Influence of Ethno Pedagogy Approach and Interpersonal Intelligence on the Results of Civic Education Learning in Pelangi Elementary school Medan
}

\author{
Indah Syasmita ${ }^{1}$, Deni Setiawan ${ }^{2}$, Daulat Saragi ${ }^{3}$ \\ ${ }^{1}$ Magister student of Universitas Negeri Medan, Indonesia \\ ${ }^{2}$ Lecturer Universitas Negeri Medan, Indonesia \\ ${ }^{3}$ Lecturer Universitas Negeri Medan, Indonesia \\ Indahsyasmita95@gmail.com
}

\begin{abstract}
This study aims to: (1) Know the differences in the learning outcomes of KDP students who are taught with the ethno pedagogical approach compared to students who are taught with the conventional approach; (2) Knowing the difference in Civic education learning outcomes of students who have high interpersonal intelligence compared to students who have low interpersonal intelligence; (3) Knowing the interaction between learning approaches and interpersonal intelligence in influencing student learning outcomes Civic education in Pelangi Medan Private Elementary School located on Jl. Bayangkara No. 417 Medan. The population in this study was the fifth grade students at Pelangi Private Elementary School, totaling 54 people. Class V/a as many as 27 students and V/ b as many as 27 students. Collecting data in this study through interpersonal intelligence questionnaires and Civic education learning outcomes test instruments. Hypothesis testing is done by the Two Way Anova test. The results showed that: (1) The learning outcomes of Civic education students who were taught with the ethno pedagogical approach were higher than the learning outcomes of Civic education students who were taught with conventional approaches $\left(F_{\text {count }}\right.$ $=21.164$ and a value of sig. 0.000>0.05); (2) Civic education learning outcomes of students who have high interpersonal intelligence are higher than those of students who have low interpersonal intelligence $\left(F_{\text {count }}=6.756\right.$ and sig. 0.012> 0.05); (3) There is an interaction between learning approaches and interpersonal intelligence in influencing student learning outcomes Civic education $\left(F_{\text {count }}=7.054\right.$ and sig. $\left.0.011>0.05\right)$.
\end{abstract}

Keyword: Ethno pedagogical approach; interpersonal intelligence; learning outcomes

\section{Introduction}

Nowadays globalization has given birth to new values, new lifestyles and new patterns of social interaction with all its consequences including sharp social inequality, broken harmony between people with rampant inter-ethnic conflict and conflict between students, changes in family values and functions, individualism and indifference, materialistic and hedonistic lifestyle, thinness of solidarity and togetherness, loss of love of domestic products, depletion of love and respect for local cultural values as part of national identity.

In the current global era, local culture and wisdom are increasingly abandoned because people have a strong tendency towards global culture with a tantalizing wrapper of modernism. In this regard, efforts to prepare human resources capable of responding to global challenges can only be answered by providing quality education. Quality education will be able to produce quality resources, have expertise, be skilled, be creative, be productive, have positive behavior and always love the culture of the motherland and its people. Quality education will be able to help students in the process of self-development, namely the 
development of all potentials, abilities, skills and personality characteristics toward positive values that will strengthen the national identity and identity they already have.

Culture can be described as the cumulative knowledge, practice and belief, about the relationship of living things (including humans) with each other and with the environment. Developing with adaptive processes and hereditary by cultural transmission (Berkes in Purniadi, 2017: 18). Culture is synonymously equated with local wisdom. According to Gondwe and Nancy in Purniadi (2017: 18) culture is a complex concept system, which includes; values, norms, beliefs and practices that are shared, created and passed down from generation to generation. Cultural systems include ways to see, interpret and understand the world. Culture is built and passed on by group members through a process of socialization and representation.

Student learning outcomes are an embodiment of the educational goals of gaining knowledge, mastering skills, and forming attitudes. Therefore, the teacher must design a learning process that involves students as a whole. Teachers are required to be able to design appropriate learning models in order to obtain high learning outcomes. Based on observations at SD Pelangi Medan shows that student learning outcomes in Civic education subjects are still low. This can be seen from the end of semester 1 grades in the following table:

Table 1 Final Examination Results for Semester Grade 5 Students of Pelangi Private Elementary School Medan T.A 2018/2019

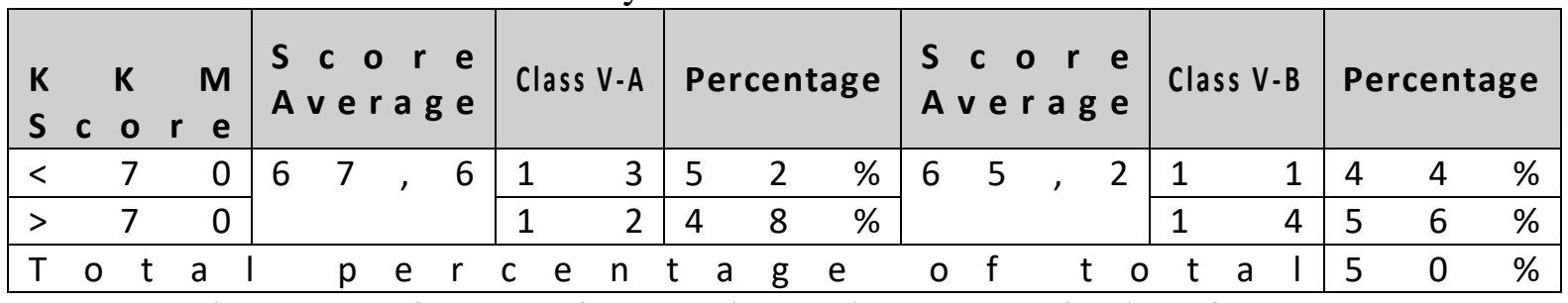

(Source: Class V-A and V-B teacher at Pelangi Elementary School Medan)

Based on the table the completeness requirement is $80 \%$ of students must achieve a value of 70 . However, it appears that in class V-A as many as 25 only 13 students (52\%) are complete and in class V-B as many as 25 students only 11 students (44\%) are complete. Then it can be seen that students are able to achieve KKM by 50\%. This proves that the value is still below the KKM.

Teacher demands today must have the responsibility of building the nation's character and culture. In this case the researcher will use the Ethno Pedagogy approach in learning Civic education. Ethno pedagogy has an important role because Ethno Pedagogy views local knowledge or local knowledge as a source of innovation and skills that can be empowered for the welfare of society. Ethno Pedagogy is the practice of education based on local wisdom in various fields such as medicine, martial arts, environment, agriculture, economy, government, calendar system and others. Local wisdom deserves to be the basis of education and culture. The introduction of local culture, especially in North Sumatra to students is needed so that students can appreciate, preserve their culture and themselves.

In addition, every child must find and develop intelligence that they have, especially interpersonal intelligence, namely intelligence in understanding the teaching and learning process by interacting with others effectively (Said, 2015: 61). Researchers are interested in developing this intelligence because at the time of observation researchers saw many children 
whose social levels were still low such as the ability to get along with others, lead, the ability to cooperate and lack empathy.

In order to improve student learning outcomes, teachers need to design and develop learning that focuses on the approaches that must be used when teaching and the intelligence those students have. Students need to be given ample opportunity to explore their abilities in learning Civic education. One effort to assist teachers in improving student learning outcomes is to apply learning with an Ethno Pedagogy approach and Interpersonal intelligence.

\section{Review of Literature}

\section{1) The Nature of Learning and Civics Learning Outcomes}

Learning is a business process carried out by someone to obtain a new change as a result of his own experience in interactions with his environment. Learning related to changes in a person's behavior towards a particular situation caused by repeated experiences in a situation.

Daryanto (2010: 12) suggests that learning is a process to obtain motivation in knowledge, skills, habits and behavior. Learning relates to the business process that a person undertakes to obtain a new change in behavior as a whole, as a result of his own experience in interactions with his environment.

Robbins (in Trianto, 2011: 15) argues that "learning is always a change in behavior or appearance, with a series of activities such as reading, observing, listening, imitating and so on. Learning as a process of creating a relationship between something (knowledge) that is already understood and something (knowledge) that is new.

Learning outcomes are measurements of the assessment of learning activities or learning processes expressed in symbols, letters and sentences that tell the results that have been achieved by each child in a certain period. According to "Susanto (2013: 5) changes that occur in students, both concerning cognitive, affective, and psychomotor aspects as a result of learning".

Based on the opinion of some experts above, the researcher concludes that learning is a change and improvement in the quality and quantity of a person's behavior in various fields that occur due to continuous interaction with their environment. While learning outcomes are results obtained by students after the students carry out learning and learning activities as well as evidence of success that has been achieved by someone by involving cognitive, affective and psychomotor aspects, which are expressed in symbols, letters and sentences.

\section{2) Ethno Pedagogy Approach}

Local culture-based learning is the creation of a learning environment and the design of learning experiences that integrate local culture as part of the learning process. Local culturebased learning, culture is integrated as a tool for the learning process to motivate students to apply knowledge. Suastra in Putra (2017: 19) said that the values embraced by indigenous people are full of values of wisdom (local genius).

Learning with culture involves the use of various forms of cultural embodiment. Learning with culture, is culture and its manifestation becomes a learning medium in the learning process, being the context of examples of concepts or principles in a subject, as well as being the context of applying principles or procedures in a subject. Learning through 
culture is a strategy that gives students the opportunity to demonstrate the achievement of understanding or meaning created in a subject through a variety of cultural manifestations. Cultured learning is a form of cultural manifestation in students' real daily behavior.

In the learning process as for the steps that can be taken by a teacher in implementing the local culture-based learning process as explained (Wahidin, 2006: 192-193) are as follows:

a. prepare material in accordance with the cultural conditions of the surrounding community that will be observed;

b. make teaching materials integrated with local culture to be observed;

c. designing learning plans that will be used in harmony with the demands of the learning objectives;

d. the selection of instructional media that requires students to be able to integrate local culture with the concepts of learning they learn at school;

e. learning begins by exploring students' initial knowledge of the culture that will be integrated in learning and guiding students to connect their culture to scientific concepts.

Based on the opinions of some of the experts above, the researchers concluded that Ethno Pedagogy views local knowledge or local wisdom as a source of innovation and skills that can be empowered for the welfare of society.

\section{3) Interpersonal Intelligence}

Interpersonal intelligence (interpersonal intelligence) is one of the eight dual intelligences expressed by Garner in Rahmi (2016: 18) eight intelligences possessed by humans including: linguistic intelligence, logical-mathematical intelligence, spatial visual intelligence, musical intelligence, kinesthetic intelligence, intelligence interpersonal, intrapersonal intelligence and naturalistic intelligence.

Through these eight types of intelligence, each individual accesses information that will enter him, because that intelligence is one way to improve students' abilities. Someone who has interpersonal intelligence is able to read social signs and cues through verbal and nonverbal communication to be able to understand and be sensitive to feelings, thoughts, intentions, temperaments, motivations and desires of others shown through attitudes and behavior.

As for the characteristics of people who have interpersonal intelligence are: (1) have many friends at school and in the environment, (2) like to socialize at school or neighborhood, (3) are very familiar with their environment, (4) many are involved in group activities outside of school hours, (5) acting as a mediator when there is a dispute or conflict between friends, (f) enjoying a variety of group games, (6) great empathy for the feelings or suffering of others, (7) likes to be sought as an "advisor" or " problem solver "by his friend, (8) really enjoys the work of others, and (9) gifted to be a leader and achievers in social science subjects.

Based on the opinion of some experts above, the researchers concluded that interpersonal intelligence is a person's ability to understand and establish communication with others so as to produce good social skills. 


\section{Research Method}

This type of research is quasy experiment with $2 \times 2$ factorial design. This research was conducted at Pelangi Private Elementary School Medan, located on Jl. Bayangkara, Medan Number 417. The population in this study were all fifth grade students of Pelangi Private Elementary School in 2019/2020 with a total of 54 students and were divided into 2 classes, namely V-A and V-B classes. Class V-A as many as 27 students and V-B as many as 27 students. Data collection techniques used in this study were interpersonal intelligence questionnaires and learning achievement tests. The data analysis technique used in this study is inferential statistical techniques. Hypothesis testing is done by the Two Way Anova test with a significant level of 0.05. Before the Two Way Anova test is performed, first the analysis requirements test is performed, namely the normality test and the data homogeneity test. The normality test was carried out by the Kolmogorov-Smirnov test while the homogeneity test of the data was carried out by the Levene test with a significance level of 0.05 .

\section{Result and Discussion}

\subsection{Result}

\section{1) Data Description}

a. Student Learning Outcomes Civic education Taught by the Ethno Pedagogy Approach

From the results of statistical calculations it is known that the learning outcomes of Civic education students who are taught with the Ethno Pedagogy approach get the lowest score of 75, and the highest score of 95, with an average of 86.85; variance of 40.67 and standard deviation of 6.38. The frequency distribution of student learning outcomes Civic education scores taught by the Ethno Pedagogy approach is presented in the following table.

Table 2 Frequency Distribution of Student Learning Outcomes Civic education

\begin{tabular}{|c|c|c|c|c|c|c|c|c|c|}
\hline I & $\mathbf{n}$ & e & $\mathbf{v}$ & $\mathbf{a}$ & F $r$ e $q$ & u e n c y & P e r c e & $n t a g e$ & $(\%)$ \\
\hline 7 & 5 & - & 7 & 8 & 2 & 2 & 7 & & $\%$ \\
\hline 7 & 9 & - & 8 & 2 & 5 & 5 & 1 & 9 & $\%$ \\
\hline 8 & 3 & - & 8 & 6 & $\varepsilon$ & 8 & 3 & 0 & $\%$ \\
\hline 8 & 7 & - & 9 & 0 & 5 & 5 & 1 & 9 & $\%$ \\
\hline 9 & 1 & - & 9 & 4 & ( & 0 & 0 & & $\%$ \\
\hline 9 & 5 & - & 9 & 8 & 7 & 7 & 2 & 6 & $\%$ \\
\hline $\mathbf{T}$ & $\mathbf{0}$ & $\mathbf{t}$ & $\mathbf{a}$ & 1 & 2 & 7 & 1 & $\mathbf{0}$ & $\%$ \\
\hline
\end{tabular}

From the table it is known that there are 55\% student learning outcomes Civic education above average and $45 \%$ student learning outcomes below average. The frequency distribution of student learning outcomes Civic education scores taught by the Ethno Pedagogy approach is shown in the following figure: 


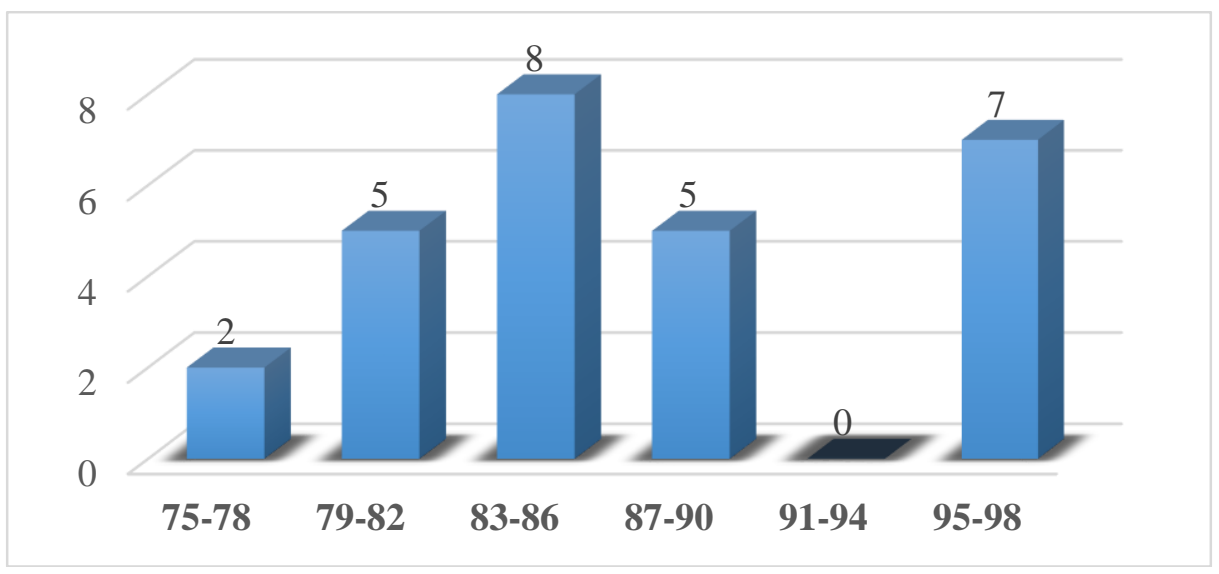

Figure 1 Histogram of Student Learning Outcomes Taught by the Ethno pedagogy Approach

b. Student Learning Outcomes Learning Taught by Conventional Approach

From the results of statistical calculations it is known that the learning outcomes of Civic education students who are taught with conventional approaches get the lowest score of 55 , and the highest score of 95, with an average of 78.52; variance of 82.34 and standard deviation of 9.07. The frequency distribution of student learning outcomes Civic education scores taught by conventional approaches is presented in the following Table.

Table 3. Frequency Distribution of Student Learning Outcomes Civic education

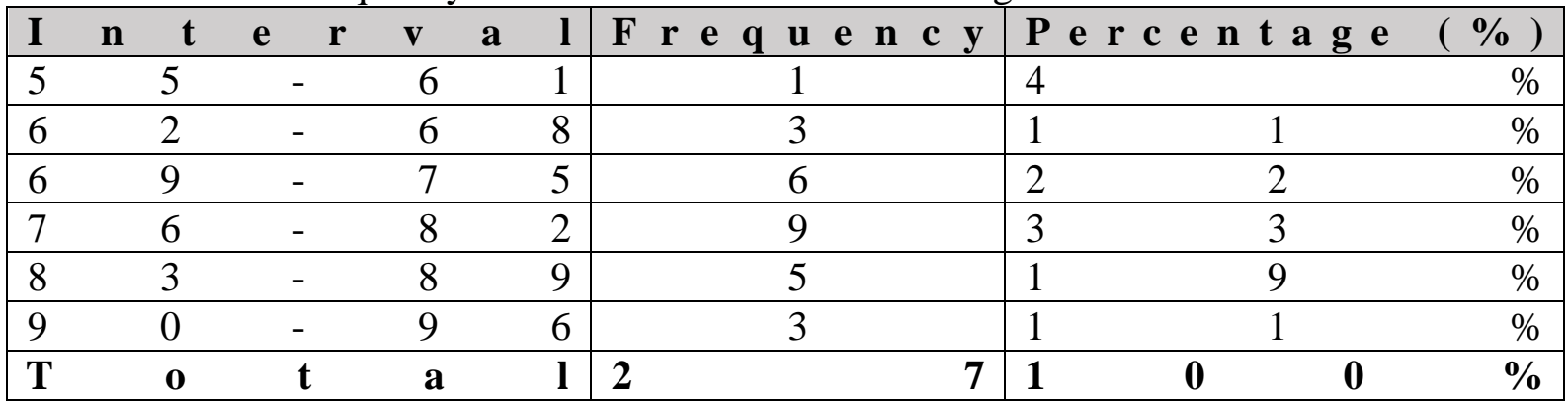

From the table it is known that there are $37 \%$ of Civic education student learning outcomes above average and $63 \%$ of student learning outcomes below average. The frequency distribution of student learning outcomes Civic education scores taught by conventional approaches is shown in the following figure: 


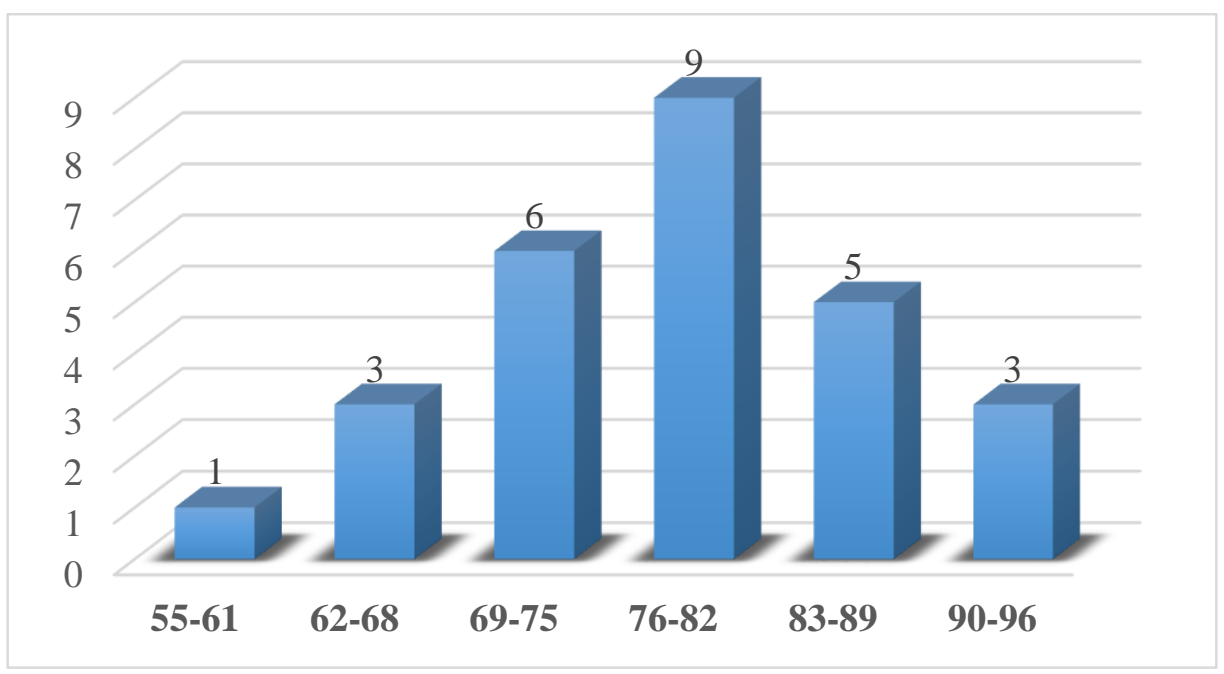

Figure 2 Histograms of Student Learning Outcomes Taught by Conventional Approaches

\section{2) Prerequisite Test}

a. Normality test

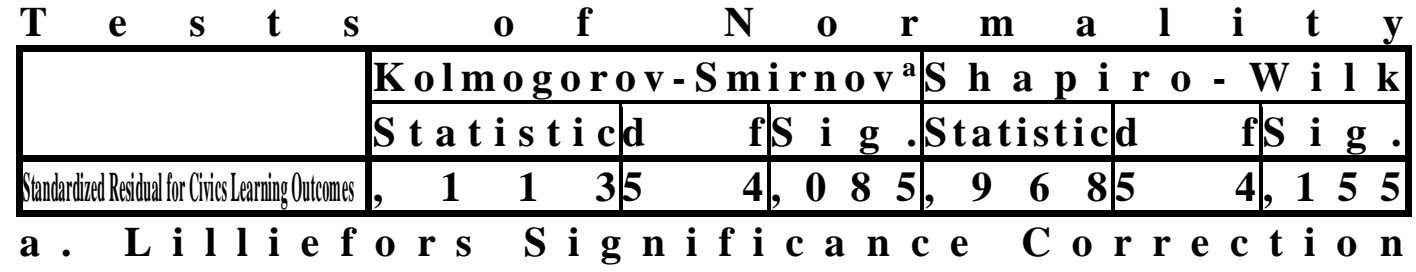

Based on the table above shows that the results of normality testing of research data obtained sig. of $0.085>0.05$, thus it can be concluded that the research data is normally distributed.

b. Homogeneity Test

Levene's Test of Equality of Error Variancesa Dependent Variable: Hasil Belajar Civic education

\begin{tabular}{|lllll|lll|lll|llll|}
\hline F & & & & d & f & 1 & d & f & 2 & i & g & . \\
\hline 2 &, & 6 & 6 & 3 & 1 & & & 5 & & 2 & 1 & 0 & 9 \\
\hline
\end{tabular}

Based on the table above shows that homogeneity testing of research data obtained sig. of 0.109>0.05, thus it can be concluded that the research data groups are relatively the same or homogeneous.

\section{3) Hypothesis Test}

Testing the hypothesis of this study using two-way ANAVA with $2 \times 2$ factorial. Hypothesis testing data can be seen in the following table: 
Table 4. SPSS Two Way Anova Calculation Results

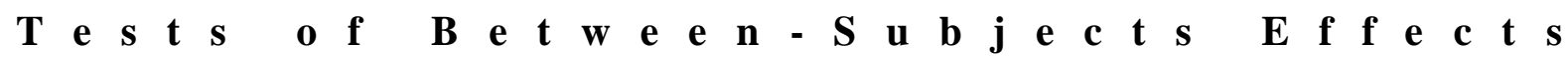
Dependent Variable: Learning Outcomes of Civic education

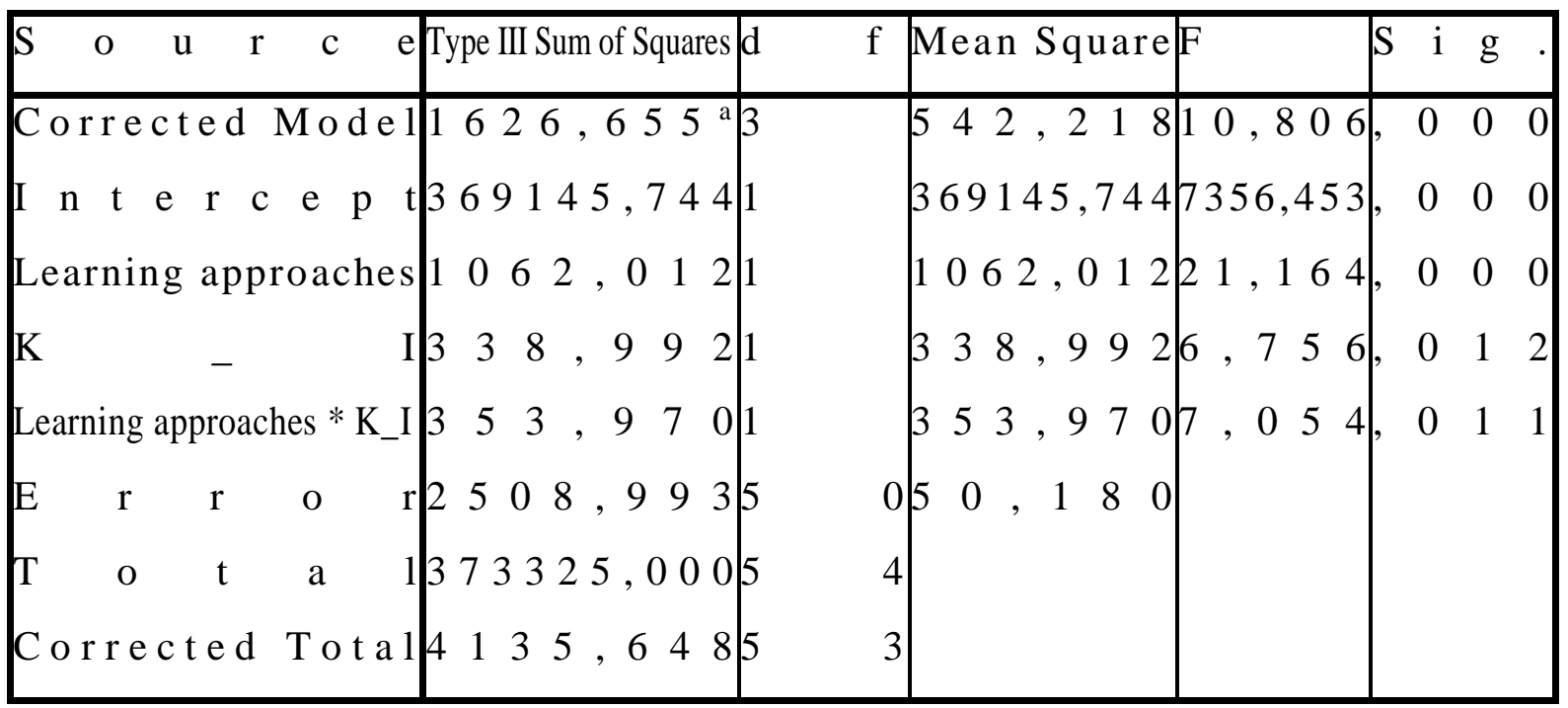

a. $\mathrm{R}$ S quared $=, 393($ A d justed R Squared $=, 357$ )

Table 5 Comparison of Civic education Learning Outcomes Based on Learning Approaches Dependent Variable: Civics Learning Outcomes

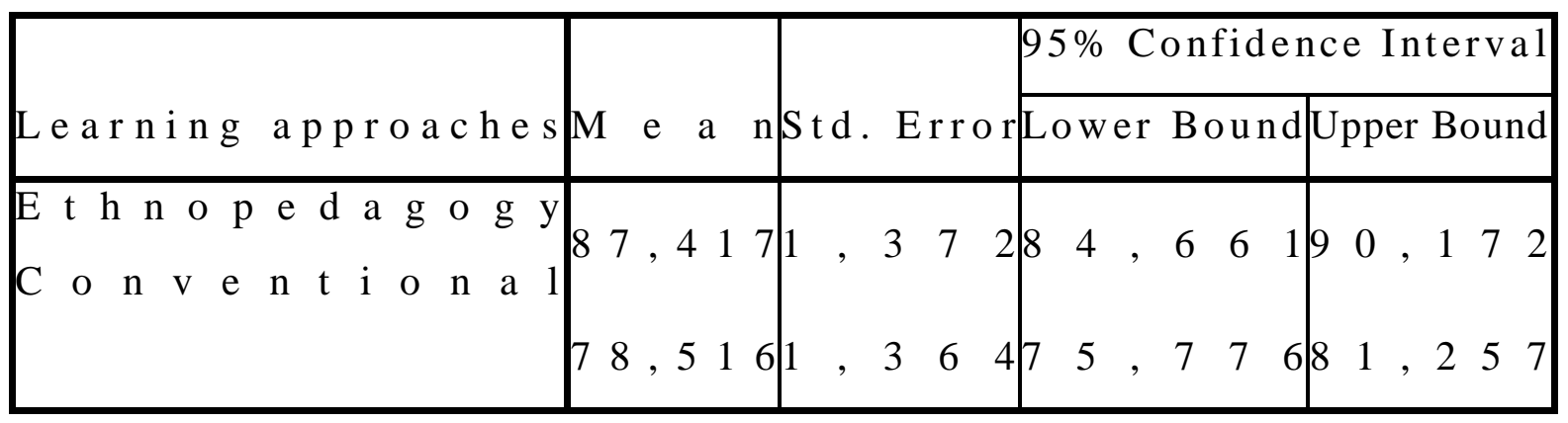

Table 6 Comparison of Civic education Learning Outcomes Based on Interpersonal Intelligence

De pendent Variable: Civics Le a r n ing Outcomes

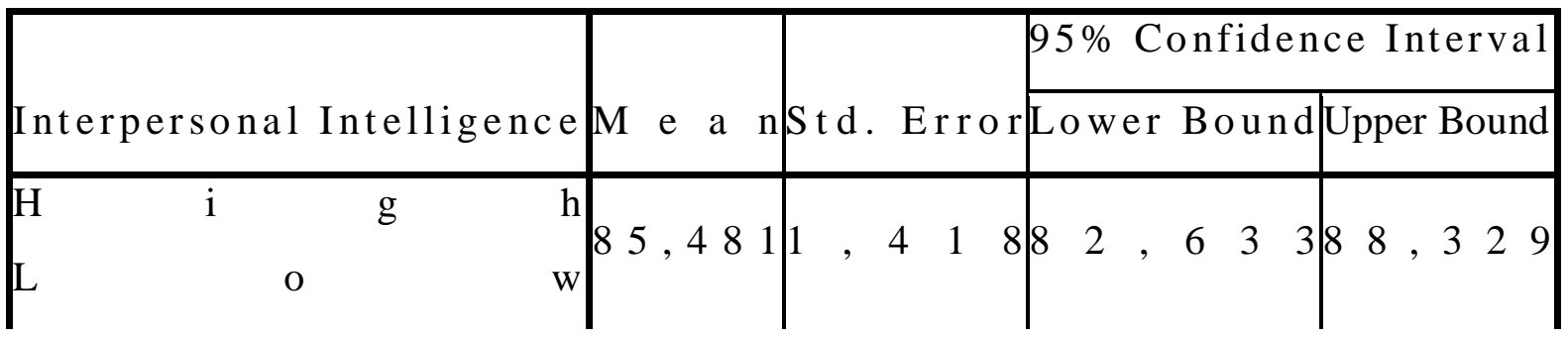




\section{First Hypothesis}

Ho : $\mu \mathrm{A}_{1} \leq \mu \mathrm{A}_{2}$

$\mathrm{Ha}: \mu \mathrm{A}_{1}>\mu \mathrm{A}_{2}$

Based on the SPSS output ANAVA calculation results in Table 4 shows that the value of $F_{\text {count }}$ $=21.164$ and the significant value of the learning approach is $0.000<0.05$. Thus it can be said that there is a significant difference between the average student learning outcomes taught by the Ethno Pedagogy approach compared to the conventional approach. Furthermore, based on the SPSS output on the comparison of Civic education learning outcomes based on the learning approach in Table 5 it is found that the average learning outcomes of Civic education students who are taught with the Ethno Pedagogy approach is 87,417. While the learning outcomes of Civic education students who are taught with conventional approaches is 78.516. This shows that the average learning outcomes of Civic education students who are taught with the Ethno Pedagogy approach is higher than the average learning outcomes of Civic education students who are taught with conventional approaches. So the hypothesis testing rejects Ho and accepts Ha. Thus it can be concluded that the learning outcomes of Civic education students who are taught with the Ethno Pedagogy approach are higher than students who are taught with conventional approaches.

\section{Second Hypothesis}

Ho : $\mu \mathrm{B}_{1} \leq \mu \mathrm{B}_{2}$

$\mathrm{Ha}: \mu \mathrm{B}_{1}>\mu \mathrm{B}_{2}$

Based on the SPSS output ANAVA calculation results in Table 4, it was found that the value of $F_{\text {count }}=6.756$ and the probability or significant value of $0.012<0.05$. Thus it can be said that there is a significant difference between the average learning outcomes of students who have high interpersonal intelligence compared to the learning outcomes of students who have low interpersonal intelligence. Furthermore, based on the SPSS output about the comparison of Civic education learning outcomes based on the level of students' interpersonal intelligence in Table 4.19 it was found that the average Civic education learning outcomes of students who have high interpersonal intelligence of 85.481. While the learning outcomes of Civic education students who have low interpersonal intelligence amounted to 80,452. This shows that the average Civic education learning outcomes of students who have high interpersonal intelligence are higher than the average Civic education learning outcomes of students who have low interpersonal intelligence. So the hypothesis testing rejects Ho and accepts Ha. Thus it can be concluded that the Civic education learning outcomes of students who have high interpersonal intelligence are higher than students who have low interpersonal intelligence.

\section{Third Hypothesis}

Ho : $\mathrm{A} \times \mathrm{B}=0$

$\mathrm{Ha}: \mathrm{A} \times \mathrm{B} \neq 0$

Based on the SPSS output ANAVA calculation results in Table 4 show that $\mathrm{F}_{\text {count }}=$ 7.054 and a significant value of 0.011 with $\alpha=0.05$. Then it can be seen that the value of sig. $0.011<0.05$ so the hypothesis testing rejects Ho and accepts Ha. Thus it can be concluded that there is an interaction between learning approaches and interpersonal intelligence in influencing student learning outcomes Civic education. The interaction of learning approaches and interpersonal intelligence in influencing student learning outcomes Civic education can be seen in the following figure. 


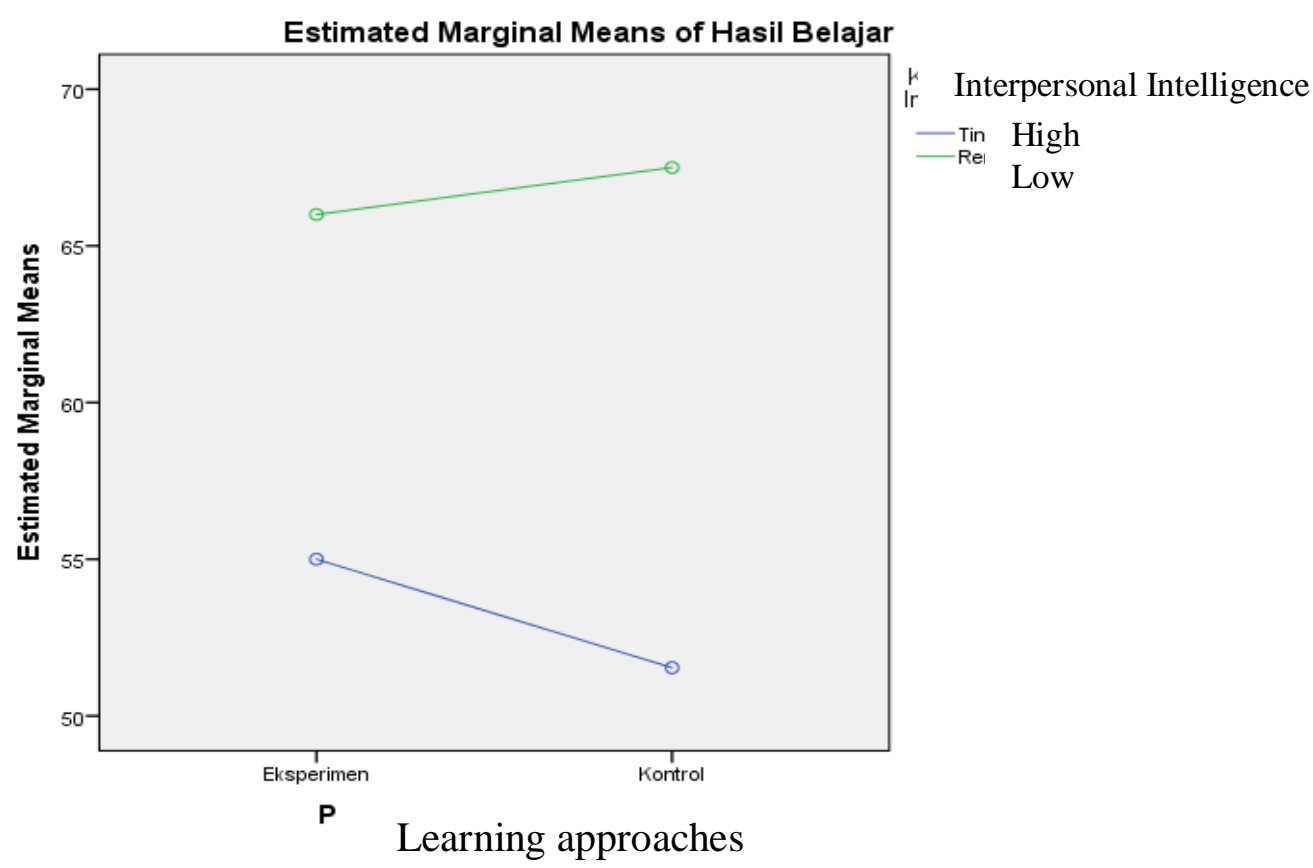

Figure 3 Interaction of Interpersonal Learning Approaches and Intelligence in Influencing Learning Outcomes Civic education

\section{4) Tukey Test}

After testing the hypothesis, it is necessary to further test using the Post Hoc with Tukey's test whose results are presented in the following table.

Table 7. SPSS Output Tukey Test Results

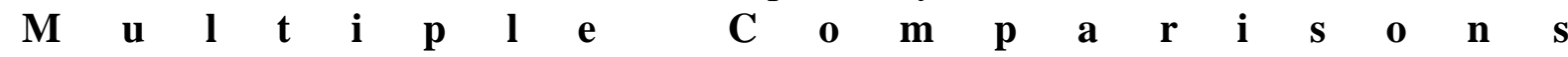
De pendent Variable: Civics Learning Outcomes $\begin{array}{lllllllll}\mathrm{T} & \mathrm{u} & \mathrm{k} & \mathrm{e} & \mathrm{y} & \mathrm{H} & \mathrm{S} & \mathrm{D}\end{array}$

\begin{tabular}{|c|c|c|c|c|c|}
\hline \multirow[b]{2}{*}{ (I) Interpersonal Intelligence (J) Interpersonal Intelligence } & \multirow{2}{*}{$\begin{array}{l}\text { Mean Difference } \\
(\mathrm{I}-\mathrm{J})\end{array}$} & \multirow{2}{*}{ Std. Error } & \multirow[b]{2}{*}{$\mathrm{S}$ i g } & \multicolumn{2}{|c|}{$95 \%$ Confidence Interval } \\
\hline & & & & Lower Bound & Upper Bound \\
\hline Etnopedagogi-KI High Etnopedagogi-KI Low & $10,17^{*}$ & 2,744 & , $\begin{array}{lll}0 & 0 & 3\end{array}$ &, 88 & 17,46 \\
\hline Konvensional-High & $14,04 *$ & 2,836 & , $\begin{array}{lll}0 & 0 & 0\end{array}$ & 6,50 & 21,57 \\
\hline Konvensional-Low & $13,93 *$ & 2,787 & , $\begin{array}{lll}0 & 0 & 0\end{array}$ & 6,52 & 21,33 \\
\hline Etnopedagogi-KI Low Etnopedagogi-KIHigh & $-10,17^{*}$ & 2,744 & $\begin{array}{llll} & 0 & 0 & 3\end{array}$ & $-17,46$ & $-2,88$ \\
\hline Konvensional-High & , 8 & 2,684 & , 480 & $-3,26$ & 111,01 \\
\hline Konvensional-Low &, 7 & 2,6332 & , 488 & $-3,23$ & 10,76 \\
\hline
\end{tabular}




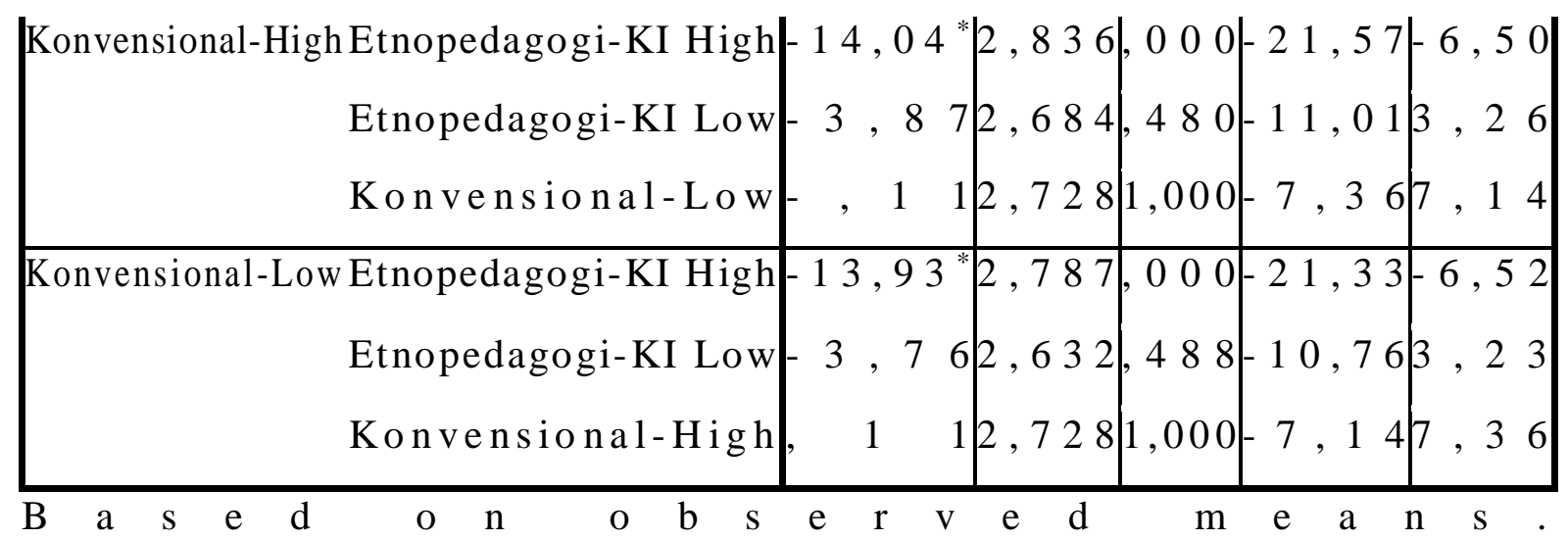

The error term is Me a $\mathrm{Square}(\mathrm{Error})=50,180$.

* The mean difference is significant at the 0.05 level

Based on Table 7, an explanation about the Tukey test can be given. The explanation is as follows:

1)Based on the results of the Tukey test it can be concluded that there are significant differences between the learning outcomes of students who are taught with the Ethno Pedagogy approach and have high interpersonal intelligence compared to the learning outcomes of students taught with the Ethno Pedagogy approach and have low interpersonal intelligence $($ Mean Diff $=10.12$; significant $=0.003$ ).

2)Based on the results of the Tukey test it can be concluded that there are significant differences between the learning outcomes of students who are taught with the Ethno Pedagogy approach and have high interpersonal intelligence compared to the learning outcomes of students who are taught with conventional approaches and have high interpersonal intelligence (Mean Diff $=14.04$; significant $=0,000$ ).

3)Based on the results of the Tukey test it can be concluded that there are significant differences between the learning outcomes of students who are taught with the Ethno Pedagogy approach and have high interpersonal intelligence compared to the learning outcomes of students who are taught with conventional approaches and have low interpersonal intelligence $($ Mean Diff $=13.93$; significant $=0,000)$.

\subsection{Discussion}

In the current global era, local culture and wisdom are increasingly abandoned because people have a strong tendency towards global culture with a tantalizing wrapper of modernism. In this regard, efforts to prepare human resources capable of responding to global challenges can only be answered by providing quality education. Quality education will be able to produce quality resources, have expertise, be skilled, be creative, be productive, have positive behavior and always love the culture of the motherland and its people. Quality education will be able to help students in the process of self-development, namely the development of all potentials, abilities, skills and personality characteristics toward positive values that will strengthen the national identity and identity they have (Suswandari, 2015).

Citizenship education lessons are known to a lot of material and memorization so that Civic education lessons are difficult for students, which causes students to be bored in the learning process. For this reason, teachers use approaches and learning strategies so that lessons are not boring and interesting. The use of Ethno Pedagogy approach teaches students 
to be aware of the local culture around their homes, fosters a sense of concern for what they have and can integrate culture as a tool for the learning process to motivate students to apply knowledge, work cooperatively, and perceive relationships between various subjects.

In the conventional learning approach the teacher's responsibility in teaching students is quite large and the teacher's role in planning learning activities is very large, because in the conventional approach the learning is centered on the teacher while in the Ethno Pedagogy approach students are stimulated to be able to solve problems, think high-level, explore information, work together and improve communication skills through the teacher's role as a mentor. In this case the learning activities do not necessarily depend on the teacher who is expected to make the classroom conditions interesting and enjoyable.

Intelligence for children has great benefits for themselves and their social development, because with the level of intelligence the child develops well and makes it easy for children to get along and be able to create new things. Education is viewed from a psychosocial perspective to foster interpersonal intelligence that takes place in the community. Interpersonal intelligence is the ability to understand situations and be able to work with others. In learning Civic education requires students to have three domains, namely knowledge, attitudes and skills. But in the learning process Civic education often students are only required to memorize a series of Civic education concepts without applying them in daily life.

Students who have high interpersonal intelligence will have more skills to control themselves, motivate themselves, have enthusiasm, persevere, and have the skills to interact with fellow students or teachers in the learning process compared to students who have low interpersonal intelligence. Therefore, students who have high interpersonal intelligence will gain more meaningful knowledge and are stored well in student memory so that it will be easy for students to answer all questions. Then, student learning outcomes Civic education will also be high.

\section{Conclusion}

Based on the results of research and discussion, several conclusions can be drawn including the following:

1. Learning outcomes of Civic education students who are taught with the Ethno Pedagogy approach are higher than the learning outcomes of Civic education students who are taught with conventional approaches $\left(\mathrm{F}_{\text {count }}=21.164\right.$ and sig. $\left.0.000<0.05\right)$.

2. Learning outcomes of Civic education students who have high interpersonal intelligence are higher than those of students who have low interpersonal intelligence $\left(\mathrm{F}_{\text {count }}=6.756\right.$ and sig. $\left.0.012<0.05\right)$.

3. There is an interaction between learning approaches and interpersonal intelligence in influencing student learning outcomes Civic education $\left(\mathrm{F}_{\text {count }}=7.054\right.$ and sig. Value $0.011<0.05)$ 


\section{References}

Daryanto. (2010). Inovasi Pembelajaran Efektif. Bandung: Yrama Widya.

Purniadi Putra. (2017). Pendekatan Etnopedagogi dalam Pembelajaran IPA SD/MI. Primary Education Journal, Vol.1, No.1, 17-23 (diakses 10 maret 2019).

Said, Budimanjaya. (2015). 95 Strategi Mengajar Multiple Intelligences. Jakarta: Prenadamedia Group.

Trianto. (2011). Model-model Pembelajaran Inovatif Beorientasi Konstruktivisme. Jakarta: Kencana.

Rahmi Putri. (2016). Pengaruh Penggunaan Model Pembelajaran Quantum Dan Kecerdasan Interpersonal Terhadap Hasil Belajar IPA Di SMP 1 Inginjaya Aceh Besar. Medan: Thesis Unimed. (Tidak dipublikasikan)

Susanto, Ahmad. (2013). Teori Belajar dan Pembelajaran di Sekolah Dasar. Jakarta : Kharisma Putra Utama. 